DOI: $10.12957 /$ transversos.2021.58646

\title{
DUPLAS LINGUAGENS ANGOLANAS: RESISTÊNCIA E RESILIÊNCIA DE UM PRESO POLÍTICO NA NARRATIVA $A$ VIDA VERDADEIRA DE DOMINGOS XAVIER (1961), DE LUANDINO VIEIRA, E NO FILME SAMBIZANGA (1973), DE SARAH MALDOROR
}

\section{DOUBLE ANGOLAN LANGUAGES: RESILIENCE AND RESISTANCES OF A POLITICAL PRISONER IN THE NARRATIVE THE TRUE LIFE OF DOMINGOS XA VIER (1961), BY LUANDINO VIEIRA, AND IN THE FILM SAMBIZANGA (1973), BY SARAH MALDOROR}

Denise Rocha

Universidade Federal Fluminense (UFF) - Brasil rocha.denise57@gmail.com

\section{Resumo:}

Crítico da ditadura de Salazar, Luandino Vieira, membro do Partido Comunista Angolano e militante do Movimento Popular de Libertação de Angola (MPLA), foi preso em 1961, época do início da guerra em prol da libertação de seu país. Encarcerado, inicialmente, em Luanda, o ativista político, permaneceu, depois de 1964, cerca de oito anos no campo de concentração de Tarrafal, em Cabo Verde. O tema da luta pela independência angolana aparece na novela $A$ vida verdadeira de Domingos Xavier (1961), que aborda a trajetória de um motorista negro, combatente do jugo colonial português. O objetivo do estudo, que reflete a faceta de resiliência e resistência do escritor e de seu protagonista, é analisar a referida narrativa e sua adaptação cinematográfica em Sambizanga (1973), segundo Hutcheon (2006), bem como o engajamento do intelectual, conforme Sartre (1947).

Palavra-Chaves: Literatura angolana; Luandino Vieira; História; Adaptação cinematográfica.

\section{Abstract}

Critic of Salazar's dictatorship, Luandino Vieira, a member of the Angolan Communist Party and a member of the Popular Movement for the Liberation of Angola (MPLA), was arrested in 1961, at the time of the beginning of the war for the liberation of his country. Initially incarcerated in Luanda, the political activist remained, after 1964, about eight years in the concentration camp of Tarrafal, in Cape Verde. The theme of the struggle for Angolan independence appears in the novel The Thrue Life of Domingos Xavier (1961), which discusses the trajectory of a black driver, a combatant of the Portuguese colonial yoke. The objective of the study, which reflects the facet of resilience and resistance of the writer and its protagonist, is to analyze the referred narrative and its cinematographic adaptation in Sambizanga (1973), according to Hutcheon (2006), as well as the engagement of the intellectual, according to Sartre (1947).

Keywords: Angolan; Luandino Vieira; History; Film adaptation.

\section{Introdução}

Figura 1

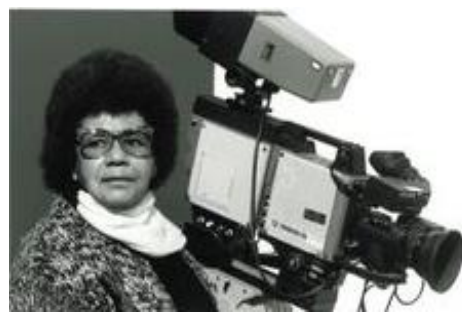

Legenda: Sarah Maldoror (1929-2020) 
Em 1973 foi lançado o filme Sambizanga, com roteiro do angolano Mário Pinto de Andrade e do francês Maurice Pons, a partir de A vida verdadeira de Domingos Xavier (1961), de Luandino Vieira. Teve direção de Sarah Maldoror que enfatizou a semelhança da adaptação cinematográfica com a narrativa, conforme declarou em uma entrevista, publicada no Bulletin, edição de 10 de abril de 1981:

Fui fiel à novela. Onde ele [Vieira] tinha um engenheiro branco que ajudava os negros, ou um mulato que era um torturador, respeitei a história. Naturalmente que ao fazerse um filme há opções políticas. Fiz um filme de acordo com as minhas ideias políticas. Fiz uma escolha quando escolhi filmar este romance. (MALDOROR apud PIC̣ARRA, 2014: p. 1)

Sarah, que estudou cinema na antiga URSS, teve influência política de seu companheiro, o angolano Mário Pinto de Andrade (1928-1990) com quem teve duas filhas. Ele foi um dos fundadores do MPLA (Movimento pela Libertação de Angola), em 1952, e presidente nos anos 1960 a 1962, que marcaram o início da luta armada angolana. (PIÇARRA, 2014, p. 1).

Militante do MPLA, movimento baseado na ideologia marxista, que vislumbrava o nascimento do homem novo na sociedade de classes (a do rico e a do pobre) foi o escritor José Luandino Vieira, ${ }^{1}$ pseudônimo de José Vieira Mateus da Graça, que viveu em bairros populares em Luanda, chamados de musseques (terras vermelhas).

Seu envolvimento em atividades políticas a favor da libertação de Angola, desde 1959, levou à sua captura, julgamento e encarceramento (1961). Nessa época, o país era um departamento de além- mar (colônia), governado por Horácio José de Sá Viana Rebelo (19571960) e por Álvaro Rodrigues da Silva Tavares (1960-1961), e sob a tutela salazarista. ${ }^{2}$

\footnotetext{
${ }^{1}$ José Vieira Mateus da Graça nasceu em 4 de maio de 1935, na Lagoa do Furadouro, Vila Nova de Ourém. Em 1938, aos 3 anos de idade, ele emigrou com a família para Angola, em busca de uma vida melhor. Sua obra literária é vasta: Contos: A cidade e a infância (1957), Duas histórias de pequenos burgueses (1961), Luuanda (1963), Vidas novas (1968), Velhas histórias (1974), Duas histórias (1974), No antigamente, na vida (1974), Macandumba (1978), Lourentino, Dona Antónia de Sousa Neto $\mathfrak{E}$ eu (1981), História da baciazinha de Quitaba (1986); novelas: A vida verdadeira de Domingos Xavier (1961) e João Vêncio, os seus amores (1974); romances: Nosso Musseque (2003), Nós, os do Makulusu (1974) e O livro dos rios (2006), livro 1da trilogia De rios velhos e guerreiros; e livro infanto- juvenil: A guerra dos fazedores de chuva com os caçadores de nuvens e Guerra para crianças (2006). Além de Kapapa: pássaros e peixes (1998), À espera do luar (1998), Papéis da prisão (2015) e a tradução de A Clockwork Orange [Laranja Mecânica] (1973). Luandino foi agraciado com vários prêmios: Grande Prémio de Novelística da Sociedade Portuguesa de Escritores -Prémio Camilo Castelo Branco- (1965), Prémio Sociedade Cultural de Angola (1961), Casa dos Estudantes do Império (1963), Prémio Mota Veiga (1963) e Associação de Naturais de Angola (1963). Em 2006, ele foi agraciado com o Prémio Camões que recusou.

${ }^{2}$ Durante o Estado Novo de Portugal, sob a égide de António Oliveira de Salazar (1933-1968), foi intensificada a repressão contra os críticos do regime. A PIDE criou um clima de terrorismo com informantes, para interceptação de correspondências e telefonemas; invasão de residências; para controle do pensamento da população, e encarceramento nos Açores, em Caxias, Peniche e Tarrafal.
} 
O escritor Luandino, vítima da PIDE (Polícia Internacional de Defesa do Estado), responsável pela coerção de todo tipo de oposição, esteve preso, inicialmente, em Luanda e, depois de 1964, na prisão no Tarrafal, em Cabo Verde, onde permaneceu 8 anos. Posteriormente, ele participou da consolidação da República Popular de Angola. Foi dirigente do Departamento de Orientação Revolucionária em 1979.

Ecos da experiência de Luandino como cidadão engajado em prol de mudanças pela libertação de Angola e sua degradação a preso político, refletiram-se em algumas narrativas, duas das quais foram transpostas ao cinema. $\mathrm{O}$ estilo neorrealista ${ }^{3}$ permeia a novela e o filme.

O tema da luta pela independência colonial, conforme a narrativa A vida verdadeira de Domingos Xavier, foi transposto para a linguagem cinematográfica em Sambizanga (1973). Tal assunto político já tinha se refletido no filme anterior, sob a direção de Sarah Maldoror, Monangambé (1968), baseado em O fato completo de Lucas Matesso (1962), de Luandino. Os protagonistas das duas narrativas são presos políticos torturados nos cárceres.

A novela A vida verdadeira de Domingos Xavier aborda a trajetória do motorista negro da firma de construção da barragem no rio Kwanza, localizada cerca de $200 \mathrm{Km}$. a sudoeste de Luanda. No estaleiro, ele mantém contato com o engenheiro branco Silvestre que lhe ensina sobre as injustiças sociais e as lutas de classes. Preso e espancado pelos agentes policiais, em sua casa no acampamento dos operários negros, Domingos é levado para o Posto dos Musseques, local de detenção de presos políticos, em Luanda. Durante os dois brutais interrogatórios, ele não revela o nome do branco politizado, nem de seus companheiros de luta, e morre por causa das torturas. À procura do companheiro detido, Maria seguiu com o filhinho para a vila e, depois, para a capital, onde, depois de passar por diversas delegacias, soube da morte cruel e inesperada de Domingos, esposo compreensivo, pai devotado e operário eficiente.

O objeto do estudo é apresentar a narrativa, A vida verdadeira de Domingos Xavier (1961), de Luandino, e sua adaptação cinematográfica em Sambizanga (1972), de Maldoror, bem como enfatizar o engajamento do intelectual, conforme Sartre (1947).

Jean-Paul Sartre (1905-1980) enfatiza na obra, Que é literatura? (1947): o papel do intelectual não-neutro, o de crítico diante da realidade histórica e social. Para o filósofo francês

\footnotetext{
${ }^{3}$ Carlos Reis, no artigo Do realismo ao neo-realismo, enfatiza que o artista neo-realista acaba por "afirmar a sua condição de entidade socialmente posicionada e, por isso, sintonizada com os problemas sociais, políticos e econômicos de seu tempo". (REIS, 1981: p. 16).
} 
“[...] a função do escritor é fazer com que ninguém possa ignorar o mundo e considerar-se inocente diante dele". (SARTRE, 1993: p. 21). Ele deve ter um comprometimento com as questões sociais; expressar críticas diante da realidade histórica e social, entre outros aspectos.

Figura 2

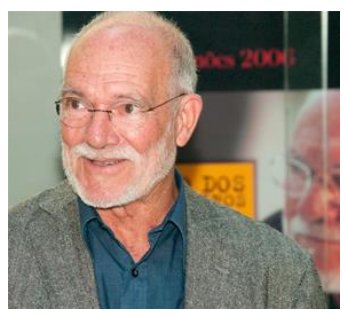

Legenda: Luandino Vieira (2011)

A trajetória de Luandino Vieira, vida e obra, revela o seu ativismo social, intelectual e literário em prol da liberdade de expressão em uma sociedade democrática e na preservação dos Direitos Humanos. ${ }^{4}$

\section{A adaptação cinematográfica (Hutcheon)}

A presente análise que será baseada nas reflexões sobre a adaptação cinematográfica de Hutcheon, se apoia em três tipos de buscas: a do governo por militantes políticos clandestinos, a do grupo pela identidade do prisioneiro da barragem de Cambembe e a de Maria pelo marido.

Na obra Uma teoria da adaptação (2006), Linda Hutcheon (1947) enfatiza que a literatura está para o "contar" e o cinema para o "mostrar", bem como define a adaptação no âmbito da tradução intersemiótica:

[...] as adaptações são recodificações, ou seja, traduções em forma de transposições intersemióticas de um sistema de signos (palavras, por exemplo) para outro (imagens, por exemplo). Isso é, tradução, mas num sentido bem específico: como transmutação ou transcodificação, ou seja, como necessariamente uma recodificação num conjunto de convenções e signos. (HUTCHEON, 2013: p. 40)

Aos detratores das adaptações de livros, Hutcheon enfatiza que: "a adaptação não é vampiresca: ela não retira o sangue de sua fonte, abandonando-a para a morte ou já morta, nem é mais pálida do que a obra adaptada. Ela pode, pelo contrário, manter viva a obra anterior, dando-lhe uma sobrevida que esta nunca teria de outra maneira.

\footnotetext{
${ }^{4}$ A Declaração Universal dos Direitos Humanos (DUDH), assinada em Paris, no dia 10 de dezembro de 1948, foi elaborada por representantes de distintas procedência jurídicas e culturais e estabeleceu, pela primeira vez, a protecão universal dos direitos humanos. O artigo I- estabelece que: "Todos os seres humanos nascem livres e iguais em dignidade e direitos. São dotados de razão e consciência e devem agir em relação uns aos outros com espírito de fraternidade"; e o artigo V-afirma: "Ninguém será submetido à tortura nem a tratamento ou castigo cruel, desumano ou degradante". (DECLARAÇÃO, 2009: p. 4 e 6)
} 
Para a autora no campo da adaptação cinematográfica:

[...] as escolhas são feitas [...] com base em vários fatores, incluindo convenções de gênero ou mídia, engajamento político e história pessoal e pública. As decisões são feitas num contexto criativo e interpretativo que é ideológico, social, histórico, cultural, pessoal e estético. (HUTCHEON, 2013: p. 153)

Em relação à representação do tempo no filme, a canadense comenta:

Costuma-se dizer que a câmera, assim como o palco, mantém relação estreita com a presença e o imediatismo. O mesmo é dito sobre a tecnologia eletrônica. A ficção em prosa, nesse esquema, tem uma linha temporal mais flexível e é capaz de invadir, com poucas palavras, o passado ou o futuro, e essas habilidades são sempre encaradas como únicas, sem equivalentes reais nas mídias performativas e interativas. Numa estética realista, de qualquer forma, as histórias nessas mídias acontecem no tempo presente, pois elas estão mais interessadas no que ocorrerá a seguir do que já aconteceu. (HUTCHEON, 2013: p. 99 e 100)

Para Linda Hutcheon, o cinema dispõe de tropos de fusão temporal em prolepse (interrupção de uma sequência cronológica e inclusão de eventos ocorridos depois) e em analepse (retorno, algo ou lembrança de um tempo antigo).

Os elementos elencados - transposição intersemiótica de um sistema de signos (palavras) em imagens (filme); adaptação da obra como sobrevida, escolha temática como "engajamento político e história pessoal" e a representação do tempo - refletem-se na adaptação de A vida verdadeira de Domingos Xavier (1961), para a tela (1973).

\section{Angola em convulsão: a luta contra a colonização lusa e o papel do MPLA (1961)}

Influenciados por lutas de independência de outros países africanos, nos anos 1950, grupos políticos angolanos de base marxista formaram células clandestinas com o objetivo de derrubar o governo do seu país, tutelado pela ditadura salazarista. O Partido Comunista Angolano (PCA), apoiado pelo Partido Comunista Português, foi fundado pelos escritores Viriato da Cruz e António Jacinto e liderado pelos irmãos Joaquim e Mário Pinto de Andrade, no dia 12 de novembro de 1955. Em dezembro de 1956, o PCA foi unido ao Partido da Luta Unida dos Africanos de Angola (PLUA) para formar o MPLA (Movimento para a Libertação de Angola). Este foi inicialmente um movimento em prol da luta pela independência, que originou uma guerra nos anos 1961 a 1974, e depois se tornou um partido político que conquistou o poder em 1974 e 1975.

Em 1960, ocorreram prisões, torturas e assassinatos empreendidos pelos agentes da PIDE. Em represália, militantes políticos atacaram vários locais em Luanda, no dia 4 de fevereiro de 1961. Tratava-se do início da guerra de independência de Angola. No artigo, Os caminhos do 4 de fevereiro, é revelado que na madrugada deste dia: 
[...] os cerca de 200 homens [...] liderados por Neves Bendinha, Paiva Domingos da Silva, Imperial Santana e Domingos Manuel Mateus atacaram o campo de Aviação, a Emissora Oficial de Angola, a Casa de Reclusão Militar e a da 7ª Esquadra da PSP. Mas foi o assalto à cadeia da Pide, a actual prisão de São Paulo, que mais notabilizou o movimento. Os relatos falam de um foguete lançado nas imediações do presídio que deu sinal para atacar, de tiroteios e de morte. No final da operação, dezenas de revoltosos perderam a vida nos vários cenários da revolta. Sete policiais e um militar português também foram mortos na madrugada de 4 e Fevereiro de 1961. (OS CAMINHOS, 2016: p. 1)

Militante ativo do Movimento para a Libertação de Angola era Luandino, perseguido pela polícia política, que certa noite chegou no seu prédio para investigações. Eles confiscaram a primeira edição dos cadernos Nzamba, que tinham textos de sua autoria:

Tinha o quarto cheio de livros de marxismo e outros considerados perigosos (e valiosos porque havia poucos em Luanda): Faziam várias voltas, biblioteca itinerante. Eu nesse tempo jogava futebol no Atlético e os treinos eram de manhã às seis no campo da Samba. Mas íamos ter à sede do Clube em plena Baixa, então depois dessa noite está a ver o teu amigo a sair de casa, já equipado de calções brancos, botas e meias, camisola e blusão por cima - para todos verem que eu era um inocente jogador de futebol - e com um grande saco de vela que eu tinha, cheio de meus melhores amigos (os livrinhos marxistas) misturados com a toalha, sabonete e uma bola por cima de tudo bem à vista. No cacimbo da manhã, cinco e tal, as luzes da cidade a apagarem-se nas ruas desertas e eu a fazer escala por casa do Adolfo e deixar os livros à mãe D. Glória e a seguir através da cidade, possivelmente com o ar mais conspirativo deste mundo. (VIEIRA, 1978: p. 14)

O escritor lembrava-se de suas atividades subversivas: ele carregava livros de conteúdo marxista, e os emprestava para colegas, em Luanda, correndo o risco de ser preso.

A novela A vida verdadeira de Domingos Xavier, concluída em 10 de novembro de 1961, evoca a clandestinidade de um movimento em prol da libertação de Angola, em Luanda e no interior (no mato, conforme expressão adotada pelos militantes e pelos guerrilheiros).

\section{A narrativa de Luandino Vieira}

Nós somos

Mussunda amigo

Nós somos!

(AGOSTINHO NETO, 2014: p. 11)

Os versos compõem a epígrafe da novela A vida verdadeira de Domingos Xavier. Trata-se do poema Mussunda Amigo, de Agostinho Neto5. Um dos personagens da novela, que é um líder político, chama-se Mussunda.

Em suas narrativas, baseadas na oralidade, Luandino cria neologismos ${ }^{6}$ e na novela sobre Domingos Xavier, e de acordo, com Valdemir D. Zamparoni, em Fiç̧ão e História em "A Vida

\footnotetext{
${ }^{5}$ O angolano António Agostinho Neto (1922-1979) foi médico, político e escritor. Foi presidente -fundador do MPLA (Movimento popular pela Libertação de Angola) e tornou-se o primeiro presidente de Angola na época de pós-independências, nos anos 1975-1979.

${ }^{6}$ Segundo José Pires Laranjeira, na obra Literaturas africanas de expressão portuguesa:
} 
Verdadeira de Domingos Xavier": "sem lançar mão de qualquer panfletarismo piegas mobiliza para tal resistência [ao colonialismo português] todos os segmentos angolanos.[...] Estão presentes personagens de todos os sexos, idades, escolaridade, matizes raciais e profissões" (ZAMPARONI, s.d.: p. 160).

A narrativa inicia com a chegada de Domingos em uma grande cadeia em Luanda (Posto dos Musseques) e termina com uma confraternização dos membros do movimento político, quando foi anunciada a morte de prisioneiro negro.

Existem dois núcleos políticos: o alfaiate Mussunda, o contínuo Francisco João (Xico Kafundanga), o antigo marinheiro Pedro Antunes (Petelo) e Miguel, em Luanda; o engenheiro Silvestre da firma de construção de barragem e seus funcionários - Timóteo, Sousinha e Domingos -, no interior. Somente, Silvestre é branco.

A ação da novela, dividida em 10 capítulos, aborda a doutrinação marxista de Domingos, esposo de Maria e pai de Bastião, sua prisão, tortura e morte, que ocorrem em três dias, de quarta-feira a sábado em dois locais: no interior (na barragem e no acampamento dos operários negros, na cadeia do posto de Administração da vila); e na capital Luanda (na Prisão dos Musseques e em outras cadeias; na alfaiataria de Mussunda, no Bairro Operário, e na casa da amiga de Maria, no bairro Sambizanga).

A narrativa não é cronológica e é permeada por distintos tempos com destaque para as memórias de Domingos, que torturado na prisão, evoca, de um lado, cenas de sua infância e, de outro, do cotidiano no acampamento dos operários negros da barragem. Ele lembra-se da diferença socioeconômica e desigualdades que vivenciava quando pequeno. Apesar disso, ele tinha habilidades, como fabricar balões de papel de seda com rabo sem vinco: os belos brinquedos eram cobiçados por muitos, principalmente, por Antoninho, filho do gerente, com o qual partilhava os apetrechos coloridos. Na vila dos trabalhadores, ele jogava futebol com as crianças e brincava com o mona Bastião. Apesar das diferenças sociais, reinava uma certa harmonia, que foi bruscamente abalada com a presença de membros camuflados da polícia política que espionavam a vida dos operários, a fim de detectar células clandestinas do partido comunista.

\footnotetext{
"A língua literária luandina surge assim na intersecção da língua natural portuguesa com a língua natural quimbunda, fornecendo aquela sobretudo o espaço lexical e a estrutura básica, interferindo esta nalguns pontos da sintaxe, introduzindo-se vocábulos crioulizados, aquimbundados, do quimbundo ou mesmo neologismos, além de certos nuances (circunlóquios, tautologias etc.) prolongarem a oralidade gramatical e expressiva do português". (LARANJEIRA, 1995: p. 314)
} 
Nessas cenas, Luandino Vieira, provavelmente, evocava suas experiências no cárcere, onde se lembrava das distintas etapas de sua vida em liberdade.

Além do panorama social destaca-se na narrativa a paisagem geográfica - a do rio Kwanza, a das plantas e a dos pássaros, e a paisagem urbana - ruas, pessoas, lojas e prédios - em uma época de intenso calor e de extrema perseguição policial.

A ação inicia com a chegada do preso político, o motorista da firma Domingos Xavier, amarrado e ferido, no Posto dos Musseques, em Luanda, depois de ter sido aprisionado em sua casa, na quarta-feira, à noite, e passado pelo posto da Administração da vila próxima. No cárcere, Domingos recordava-se de sua vida no estaleiro de construção da barragem de Cambembe. Ele estava no turno diurno, graças à intermediação do branco, o engenheiro Silvestre, um dos responsáveis pela obra, e membro de um movimento político. O operário vivia no acampamento dos negros, enquanto que os operários brancos residiam em condições melhores. Domingos estava preocupado com o desaparecimento do outro trabalhador, o Sousinha. Silvestre, não estava alarmado com isso. Anteriormente, Timóteo já tinha sido preso. O engenheiro tinha defendido o direito dos funcionários pretos de não comerem pratos estranhos (sopa e macarrão) na cantina e, sim, de trazerem as comidas de suas casas.

Em conversa com Sousinha, Domingos confidenciou:

-Você ouve, mano! Não é daqueles brancos que te faz bem para você gostar dele, para ficar satisfeito porque o coração dele manda. Não! Esses eu conheço bem, mano Sousa! Esses eu conheço muito bem... Se você um dia não cumprimenta de tirar o chapéu, dizem logo és um ingrato, todos os negros são assim, acabam te mandando no Posto. Este não, amigo Sousa! Este, quem manda é a cabeça dele... (VIEIRA, [1979]: p. 22)

O militante Xico, que vivia em Luanda, sofreu uma transformação. Antes ele era alienado, muito vaidoso, jogava futebol e tinha várias namoradas, até certo dia, quando conheceu o alfaiate Mussunda que lhe esclareceu sobre a desigualdade social da vida dos ricos e dos brancos, em várias conversas no clube Botafogo, nos finais de semana:

E mais tarde, num dia de grande chuva de Abril, amigo Mussunda tinha falado umas conversas que lhe abriam os olhos: mostrou que não havia branco, nem preto, nem mulato, mas só pobre e rico, e que rico é inimigo do pobre porque quer ele sempre pobre. Aí Xico tinha ficado admirado, refilara com Mussunda - como então, se os ricos dão trabalho, se os ricos dão o dinheiro, se os ricos dão a esmola nos pobres, se não havia rico, pobre não tinha trabalho. (VIEIRA, [1979]: p. 36 e 37)

Mussunda tinha explicado sobre a luta de classes na sociedade capitalista, no círculo vicioso da exploração do proletário (do pobre) pelo burguês (do rico):

[...] O alfaiate riu muito na cara do rapaz. Mas depois lhe explicou muitas coisas, como o rico dá de maneira que pobre é sempre pobre e trabalha para ele ser sempre rico, se não havia rico não havia pobre, todo mundo era igual. Pois é, mais então se dinheiro de rico fica quieto, dá mais dinheiro? Não pode! Só com o trabalho do pobre, mano

Revista Transversos. Rio de Janeiro, n. 22, ago. 2021. 
Xico, é que o dinheiro dá mais dinheiro para o rico ficar mais rico, e o pobre? Sukua! Sempre na mesma! (VIEIRA, [1979]: p. 37)

No final da tarde do segundo dia, sexta-feira, em Luanda, Domingos acordou assustado, por causa da chuva. Em estado de sonolência por causa dos ferimentos no corpo e na cabeça, ele começou a se lembrar das mulheres do acampamento que lavavam roupas nas pedras e da paisagem do rio Kwanza, transformada por causa da intervenção humana para a construção da barragem. A noite, foi despertado por um cipaio a pontapés; e foi novamente torturado. Ele teve as orelhas puxadas, murros no pescoço, aproximação da luz da lâmpada do candeeiro e espetada da nádega com uma agulha quando suas mãos e seus pés estavam amarrados em uma cadeira, $O$ preso levou bofetadas, murros e pontapés nos joelhos, no rosto, peito e rins e teve os pés pisados com sapatos de solas grossas. Atirado moribundo em uma cela coletiva, morreu. Um deles limpou seu rosto ensanguentado e os demais cantaram uma canção melancólica (cap. 8).

Solidários, os outros presos se compadecem com o retorno do moribundo:

Um homem virou Domingos Xavier de costas e, na pálida luz do luar, a cara inchada do tractorista apareceu entre os farrapos da camisa suja de sangue. Um vento de frio correu no meio dos homens. Era terrível aquele cara, quase sem feições, sangrentas, mas um sorriso teimoso nos lábios. O mais miúdo se abaixou e, tirando, um lenço começou a limpar com cuidado o sangue na cara de Domingos Xavier. O homem alto e forte deixou-lhe, depois, com muito jeito, no chão, enquanto um velho, ainda cheirando a vinho, começava a choramingar. Alguém que tinha um cobertor abriu-lhe em cima do tractorista e cobriu com ele o corpo magro e torturado. (VIEIRA, [1979]: p. 77)

Um rapaz da Funda começou a cantar, acompanhado do coro dos demais presos:

\author{
Uexile kamba diami \\ Una uolobita \\ Uafu \\ Mukonda kajímbuidiê. (VIEIRA, [1979], p. 78) \\ Tradução: Era meu amigo \\ Aquele que vai a passar \\ Morreu porque não quis falar.
}

$\mathrm{Na}$ noite do mesmo dia, no bairro Operário, é realizada a festa para reanimar os companheiros do movimento e homenagear os presos, ao som dos Ngomas. Petelo e Zito chegam e informam sobre a morte de Domingos. Mussunda anuncia a tragédia e enfatiza que ele começou sua verdadeira vida no coração das pessoas (cap. 10). Abaladíssimo, ele anuncia:

- Irmãos angolanos. Um irmão veio dizer que mataram um nosso camarada. Se chamava Domingos e era tratorista. Nunca fez mal à ninguém, só queria o bem do seu povo e da sua terra. Fiz para esta farra para dizer isto, não é para acabar, porque a nossa alegria é grande: nosso irmão se portou como homem, não falou os assuntos do povo, não se vendeu. Não vamos chorar mais a sua morte porque Domingos António Xavier, você começa hoje a sua vida de verdade no coração do povo angolano...

E nem o vento se atrevia a xuaxalhar as folhas das mulembas quando Mussunda alfaiate falava assim. (VIEIRA, [1979]: p. 94)

Figura 3 


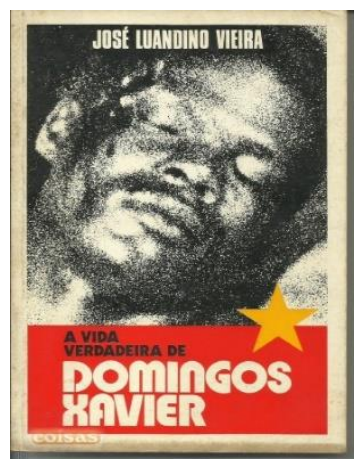

Legenda: Capa da 2.ed. da obra publicada pelas Edições 70, de Lisboa, 1975

A importância do papel político do personagem fictício Domingos Xavier no imaginário partidário angolano é destacado no artigo Cárceres da liberdade: As portagens de uma vida verdadeira, de Clauber Ribeiro da Cruz:

Através de uma narrativa rápida, com uma linguagem vigorosa e ritmada, a figura do herói Domingos Xavier caracteriza-se como um símbolo importante contra o colonialismo em Angola, já que seu cárcere e morte abrem caminho para a libertação, isto é, a verdadeira vida dentro do coração do povo angolano. (CRUZ, 2016: p. 248)

Referência heróica na mente de membros do MPLA, Domingos Xavier, que se imolou para preservar a identidade de seus camaradas na célula clandestina do partido, teve sua trajetória transposta para a linguagem cinematográfica.

\section{O filme "Sambizanga" (1973), de Sarah Maldoror}

A militante política e cineasta francesa, Sarah Maldoror (1939), ${ }^{7}$ em entrevista concedida a Pedro Cardoso, publicada com o título "Em nome da moral fazem-se guerras", no Novo Jornal, de Luanda, na edição de 28 novembro de 2008, declarou: "Sou de Guadalupe, faço parte dos escravos que foram enviados para lá. Sou Africana”. (MALDOROR, 2008: p. 14). ${ }^{8}$

Ela foi uma das fundadoras do Grupo de Teatro Les Griottes (1956), em Paris, que produzia a "negritude” por meio de adaptações de Jean-Paul Sartre e Aimé Césaire. ${ }^{9}$

\footnotetext{
${ }^{7}$ Sarah Ducados nasceu na ilha de Guadalupe, filha de mãe francesa e de pai natural da ilha de Maria Galante, nas Antilhas Francesas. Maldoror é seu nome artístico, que foi escolhido em homenagem à obra Contos de Maldoror, do escritor francês Lautreamont,

${ }^{8}$ Sarah foi uma das fundadoras do Grupo de Teatro Les Griottes (1956), em Paris, que produzia a "negritude" por meio de adaptações de Jean-Paul Sartre e Aimé Césaire. Contemplada com uma bolsa de estudos de cinema pela URSS, nos anos 1961 a 1962, ela estudou no Studio Gorki, em Moscou, com os professores Serguei Guerassimov (1906-1985), e Mark Donskoi (1901-1981). Sarah foi assistente de realização de Gillo Pontecorvo no famoso A batalha de Alger que ganhou o Leão de Ouro no festival de Veneza, entre outros prêmios.

${ }^{9}$ Contemplada com uma bolsa de estudos de cinema pela URSS, nos anos 1961 a 1962, Sarah estudou no Studio Gorki, em Moscou, com os professores Serguei Guerassimov (1906-1985), e Mark Donskoi (1901-1981). Ela foi assistente de realização de Gillo Pontecorvo no famoso filme, A batalha de Alger, que ganhou o Leão de Ouro no festival de Veneza, entre outros prêmios.
} 
Sarah Maldoror adaptou duas narrativas de Luandino Vieira para o cinema: O fato completo de Lucas Matesso (1962) em Monamgambé (1968) ${ }^{10}$ e A vida verdadeira de Domingos Xavier (1961) em Sambizanga (1972).

No artigo A vida verdadeira do Sambizanga em tempos de viragem, Edimara Lisboa compara as duas obras cinematográficas:

Enquanto a curta Monamganbé é um filme de cunho universalizante, tratando de modo abrangente e simbólico questões como a tortura, a incompreensão linguística e a solidão, o longa-metragem Sambizanga documenta ficcionalmente momentos preliminares e fatos locais que culminaram no início da luta armada contra o Império Português em Angola. (LISBOA, 2016: p. 3)

As filmagens de Sambizanga foram realizadas em Brazaville, no Congo, durante 7 semanas e montado em Paris (10 semanas). Os artistas amadores eram militantes do MPLA (Movimento pela Libertação de Angola) e do PAIGC (Partido para a Independência de Guiné e Cabo Verde). A equipe técnica era predominantemente francesa, com destaque para Claude Agostini, diretor de fotografia.

Em Portugal, inicialmente, a exibição do filme foi suspensa, apesar de ter sido anunciada para o dia 19 de outubro de $1974 .^{11}$

$\mathrm{Na}$ entrevista concedida por Maldoror, ela comentou sobre a presença feminina:

CARDOSO. Sambizanga relata a busca de uma mulher pelo seu marido, preso por razões políticas. É uma visão feminista?

MALDOROR. O filme mostra que as mulheres também participaram da luta. Mulheres com filhos nos braços que lhes tinham que explicar por que o pai partiu, quais os riscos e a própria realidade. (MALDOROR, 2008: p. 15)

Em relação ao pioneirismo do filme, Maria do Carmo Piçarra, em Luandino Vieira filmado

por Sarah Maldoror, explica que ele se distinguiu por três motivos:

[...] por ter prenunciado a criação de uma produção de cinema especificamente africana: por ser uma obra ficcional inspirada pelos movimentos de libertação africanos - no caso específico, pelo angolano, e por optar por expor um ponto de vista feminino. Visualmente, bem conseguido - com grandes planos notáveis -, bem montado, é fragilizado por um certo didactismo político embora a opção de Maldoror de filmar um registo íntimo o distinga de um cinema militante de vocação colectivista, dominante no período em que foi realizado. (PIÇARRA, 2014: p. 1)

\footnotetext{
${ }^{10}$ Monangambé foi apresentado no Festival de Cannes (1971), selecionado para a seção paralela da Quinzena dos Realizadores, em representação de Angola, para que a luta política em prol da libertação de Angola fosse conhecida. O filme foi premiado no Dinar Film Festival (França), com o International Critics Prize no Carthage Film Festival (Tunísia) e foi selecionado para o terceiro Festival Panafricain de Ougadougou (FESPACO), em 1972.

${ }^{11}$ Segundo o produtor e exibidor António da Cunha Telles, ele participou de uma reunião com o Ministro da Defesa do I e II governos institucionais, Mário Firmino Miguel, que lhe informou que a causa da suspensão naquele momento, era que a sociedade portuguesa estava dividida, por causa da situação política nas colônias. Cunha Telles comentou: "Foi um pouco embaraçoso. Não se tratou de espírito de censura. Receava-se que a exibição do filme exacerbasse a situação do conflito e viesse a causar distúrbios por parte das pessoas que estavam contra a independência de Angola”. Posteriormente, o filme foi exibido no cinema Universal com a presença de Luandino Vieira e outros militantes do MPLA. (PIÇARRA, 2014: p. 1).
} 
Maldoror explicou sua motivação em realizar este filme que mostra uma história ficcional, ocorrida no início dos anos 1960, época da organização da luta armada contra Portugal (Ecran, 73: p. 71, mai. 1973):

Mostro com as pessoas tentam organizar um movimento da resistência. As pessoas culparam-me... por ter escolhido actores que, disseram, são demasiado belos. Bem, são de facto pessoas negras que são belas e é tudo... Em termos de ritmo do filme, tento recriar o ritmo lento que caracteriza a vida africana. Nada é inventado. Tudo o que mostro no filme deriva da minha própria percepção dessa realidade. (MALDOROR apud PIÇARRA, 2014: p. 1)

Fato é que Sarah acompanhava Mário Pinto de Andrade, na Guiné-Conacry, no ano de elaboração do filme (1972). Nessa época, o MPLA já apresentava sinais de ruptura, principalmente entre Mário e Agostinho Neto, futuro primeiro presidente de Angola. Era preciso evocar as raízes políticas do movimento, bem como o legado biográfico e literário do militante Luandino, preso em Cabo Verde, até 1972.

\subsection{A transposição intersemiótica: da palavra à imagem}

No artigo Sarah Maldoror: o cinema da noite grávida de punhais, Rachel Scheffer inclui o esclarecimento da cineasta sobre a filmagem fora de Angola:

Filmei no Congo-Brazzaville porque não era possível fazê-lo em Angola. O CongoBrazzaville era independente e, além disso, interessava-me a arquitectura da prisão de Brazzaville. O rio Congo também era impressionante. Quando faço um filme, os décors são tão importantes quanto o texto. [...] Quando vi o rio Congo, soube imediatamente que era ali que iria filmar. Cinematograficamente, tanto a prisão, quanto o rio me pareciam excepcionais. (MARDOROR apud SCHEFFER, 2015: p. 149)

Enquanto que a novela A vida verdadeira de Domingos Xavier (1961), de José Luandino Vieira, não segue a cronologia dos acontecimentos vivenciados pelo protagonista, o filme Sambizanga segue a ordem natural dos fatos.

$\mathrm{Na}$ majestosa abertura do filme ${ }^{12}$ surgem imagens de um rio com águas turbulentas e barulhentas. Ao fundo soa uma canção com o refrão "Oh, oh, oh, oh, oh, Monangambé”, que significa carregador, contratado, trabalhador braçal. A expressão seria utilizada para chamar os negros para o trabalho, além de ser o título do primeiro filme político de Sarah Maldoror.

A paisagem fluvial intocada alterna-se e contrasta-se com o amplo local do estaleiro da firma de construção da barragem que tem guindastes, máquinas diversas e tratores-caçambas. Alguns funcionários usam macacões, capacetes e protetores de olhos e de ouvidos. Os outros, trabalhadores braçais, trajam calças curtas ou longas, a maioria sem camisas e chapéus. As grandes

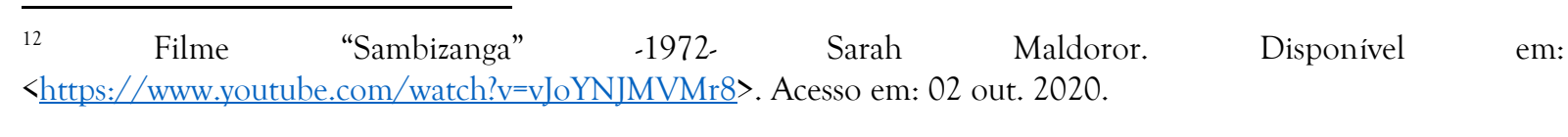


pedras são transportadas nos tratores- caçambas; um dos motoristas é um funcionário negro, alto e musculoso [Domingos, protagonista da trama]. Elas são despejadas próximas do rio. Parte delas é carregada por braços humanos e jogada no solo para serem quebradas; outras são trituradas, a marretadas, e carregadas em baldes nas cabeças pelos trabalhadores. Os detritos pequenos seguem por esteiras de metais ascendentes de um guindaste. Trata-se da fase inicial de redução de pedras que serão a base das muralhas da barragem.

Nas cenas de trabalho pesado, humano e tecnológico, um funcionário branco conversa com Domingos e diz: "Vamos falar logo à noite em minha casa!", revelando ter intimidade com o operário, fato que chama a atenção do colega dele. Posteriormente, no descanso para beber água, o jovem quer saber detalhes desse relacionamento:

COLEGA: - Você conhece bem o seu Silvestre.

DOMINGOS: - Sim, conheço.

COLEGA: - Ele fala bem contigo.

DOMINGOS: - Fala. Aliás, ele disse que eu sou bom tratorista. Onde ele vai, eu vou também. Eu vou te dizer uma coisa, mas não diga a ninguém, jura?

COLEGA: - Eu juro que não digo a ninguém.

DOMINGOS: - Eu conheço muito bem os brancos. Mas esse branco é muito nosso amigo. Não esqueça!

$\mathrm{Na}$ abertura é mostrado o contraste da vida dos angolanos, alguns trabalham de forma digna, outros, na condição de quase escravos, no entanto, a fala de Domingos revela a crença em mudanças, a partir de seu contato com Silvestre, o branco, com o qual trabalhou em outras empreitadas. Ao som de "Monangambé", são apresentados o título do filme e os nomes de sua equipe com imagens impactantes das águas do rio, caudalosas e assustadoras.

A ação inicia com o retorno do tratorista ao acampamento, onde Maria com o pequeno Bastião o esperam. Ele brinca com os meninos que jogam futebol e com o filhinho. Comem e descansam. Domingos vai até o dormitório coletivo dos rapazes e entrega a um deles panfletos que chegaram de Luanda, com a recomendação de distribuí-los. O rapaz lê em voz alta:

A todos os patrícios angolanos,

A cada dia que passa ajunta mais dor, a nossa dor comum, fome nas famílias, miséria nas casas, trabalho forçado nas estradas. Tudo isso é obra do colonialismo português. Para acabar com a exploração e a dominação estrangeira na nossa terra devemos reforçar a organização do nosso movimento. Formar grupos clandestinos, organizar para lutar melhor.

Percebe-se que Domingos atua diretamente no movimento para derrubar o governo colonial. Provavelmente, ele recebeu das mãos do engenheiro Silvestre os panfletos, considerados 
subversivos, e vai ser identificado pela cúpula administrativa e policial de Luanda como membro ativo da célula terrorista. ${ }^{13}$

Imagens da paisagem da floral são vistas pelo prisioneiro, ao ser levado para o Posto dos Musseques, em Luanda, e são alternadas com cenas de crianças que brincam com bolinhas de gude. Tirado do carro por policiais, e apesar de amarrado e ferido, Domingos continua a ser agredido na porta da delegacia. Zito, que jogava com outros meninos, corre até seu avô e o informa sobre a chegada de um preso desconhecido.

O velho senhor segue com o menino para comunicar o fato a outro membro do movimento, Francisco João (Xico), durante o seu expediente no prédio dos Correios, Telégrafos e Telefones. Ele estava ausente, mas iria receber o recado sobre as visitas. Enquanto aguardam passar o tempo de espera, o avô e o neto saem. $\mathrm{O}$ menino olha as vitrines que tinham produtos diversos e caros para ele e sai a pescar com o avô. Xico recebe o recado e os procura na praia. Todos vão almoçar em um restaurante popular, onde um rapaz toca violão. Xico fica consternado sobre o desconhecimento da identidade do novo preso.

Ao som de uma música melancólica, com voz feminina em língua portuguesa sobre a vida, "Caminho do mato, caminho do amor"-, Maria segue a pé, com o filhinho amarrado nas costas, por uma longa estrada de terra rumo ao posto policial da Administração. ${ }^{14}$

Maria segue melancólica pela estreita estrada deserta, passa por uma igreja e chega a uma fonte comunitária com torneiras de água, onde mães lavam crianças e roupas. Ela refresca a si e ao filhinho. Chega no prédio da Administração, que ostenta uma bandeira portuguesa esvoaçante. ${ }^{15}$ Depois de 12 anos, ela chega, à noite, na casa da família de uma antiga conhecida,

13 Depois da entrega dos papeis, o operário Domingos retorna para sua casa. O menino Bastião chora desesperadamente nos braços do pai, que o nina com amor, e Maria faz cafuné na cabecinha dele. O conhecido jeep dos policiais chega e dois rapazes fogem. Inesperadamente, Domingos é retirado da moradia por 6 cipaios negros, conduzidos por um motorista branco. Ele reage e é jogado na viatura. Maria corre para fora e tenta abrir a porta da condução. Seu esposo grita não, várias vezes, e pedem que ele cale a boca, mas nada conseguem. Apesar de estar à mercê dos cipaios, ele não entende que não deve provocar mais violência. Recebe golpes de cassetete, sendo contido com cordas. Maria é consolada por vizinhos. Duas senhoras, que fumam cachimbo, conversam com ela em quimbundo. Recebe prendas, frutas e carne. A mãe de Sousinha, militante desaparecido, cuida de Bastião, e a aconselha a ir ao posto da Administração do Dondo, para exigir notícias do paradeiro do marido. As cenas com Domingos, sendo amarrado no carro, se alternam com as de sua casa.

${ }^{14}$ Xico segue até a casa de outro membro do movimento político, Miguel. Encontra sua mãe e sua irmã Bebiana. Ambos já se gostam e saem para encontrar o jovem. Xico conta a ela que mudou muito depois de suas conversas políticas com o alfaiate Mussunda. Passa as notícias alarmantes a ele.

${ }^{15} \mathrm{O}$ cipaio Tornelo é seu conhecido, cujo superior retorna e informa à moça que Domingos seria um bandido, que queria matar todo mundo. Ela deveria evitar complicações e retornar para sua casa. Mas, Maria, de joelhos, se põe a gritar que teriam matado Domingos. O responsável a ameaça de fazer com ela o mesmo que teria feito com seu 
Sá Teté, esposa de sô Cardoso, que a acolhe com todo carinho e a abraça. Uma vizinha amamenta o nenê Bastião. De manhã, acompanhada por Joãozinho, filho do casal, Maria cruza com Zito, e segue para um posto policial, onde o secretário a informa que, por não ser preso político, o marido dela estaria no posto da Baixa. Segue com o menino ao Largo da Mutamba, que não reconhece sem a estátua de Pessoa e as três mulembas, árvores imensas e centenárias.

Profundamente ferido, Domingos conversa com outro preso. Maria chega ao prédio da PIDE que tem uma placa identificadora, mas foi escorraçada.

No cárcere, presos andavam em círculos no pátio que tem chuveiros. Dois guardas na torre de vigia observam os movimentos. ${ }^{16} \mathrm{O}$ preso passa por um primeiro interrogatório, mas nega conhecer Sousinha e Timóteo. O delegado tenta, de forma pacífica, induzi-lo à delação. O impaciente escrivão começa a esmurrar a mesa, como forma de intimidação. O preso, faminto e sedento, recebe um sanduíche de presunto e um copo de cerveja e é agredido, tendo a boca cortada, por golpe do escrivão. Recebe inúmeras pancadas pelo corpo todo.

Miguel foi ao acampamento dos negros, na barragem, onde encontra no local das lavadeiras, a mãe de Sousinha. Ela revela o nome do agredido, Domingos Xavier, e as circunstâncias de sua prisão violenta.

Domingos recebe uma caneca de café com um bilhete de Timóteo para que não revelasse nada. $O$ papelzinho foi engolido para não deixar vestígios. Maria foi a outro posto policial, mas Domingos também não estava ali.

esposo, caso não se calasse. Torneto tenta acalmá-la, mas ela o chama de cipaio de merda que estaria com os brancos. Ele lhe informa que Domingos teria sido levado por João e Matumba para a capital. Ela retruca que o esposo não conhecia nenhum branco e não falava com eles. Seu desespero se intensifica quando é revelado que ele teria apanhado. Compadecido, o cipaio a acompanha até a parada de ônibus. Decidida, a moça embarca para Luanda, em uma longa viagem, ao som de "Caminho do mato, caminho do amor".

${ }^{16}$ Miguel, outro membro do movimento, viajou, de carona em um caminhão de transporte de frutas, até o Bairro Operário, onde mora Mussunda, ativo membro do movimento político. Dois homens costuram, enquanto o alfaiate corta o pano e conversa com dois estudantes, explicando que não existiriam nem brancos, mulatos e pretos, mas, sim, ricos e pobres. Miguel chega e informa Mussunda a respeito do preso desconhecido, alto e forte. É encarregado de uma missão, a de ir até a o acampamento da barragem para saber a identidade do preso. E é convidado para uma festa no sábado. 
Figura 4

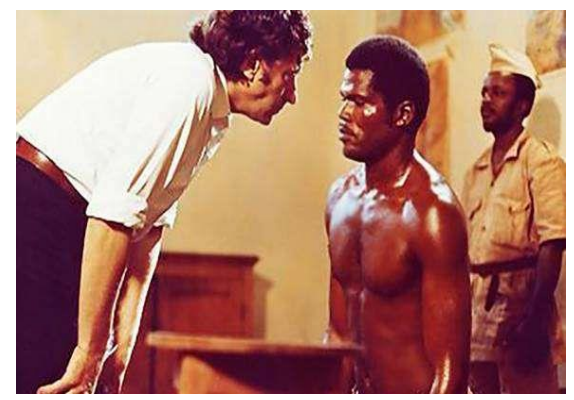

Legenda: Segundo interrogatório de Domingos Xavier (Domingos Oliveira), conduzido pelo escrivãotorturador

Reconduzido a um segundo interrogatório, Domingos encontra-se muito ferido e sangrando e tem muita dificuldade em caminhar. Novamente, se nega a dizer o nome do branco. Um agente policial entra na sala, e o prisioneiro o reconhece como aquele funcionário da firma, que tinha sido denunciado por Sousinha como policial infiltrado. Ele acusa o tratorista de conhecer o branco e Domingos cospe em seus pés, enervando o escrivão que pega a palmatória. O cipaio negro esboça um olhar apavorado pela tortura que seguiria, mas que não é mostrada. Figura 5

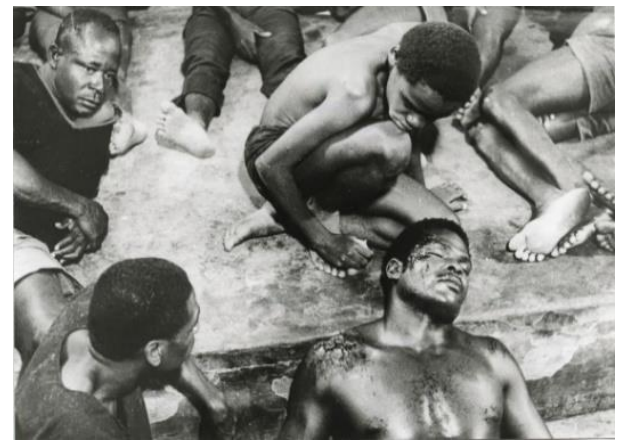

Legenda: Solidariedade dos presos com o companheiro morto.

Domingos é levado moribundo à cela coletiva. Um dos presos limpa o seu rosto inchado, machucado e sangrento, e acaricia seus cabelos. Os companheiros começam a entoar um canto fúnebre em sua homenagem. No pátio da prisão, pessoas correm.

Maria vai até o Posto dos Musseques, entrega um bilhete ao porteiro e adentra ao prédio. Ela é vista por Zito que joga com bolas de gude e corre avisar a seu avô. A jovem sai, muda e alquebrada, de uma das salas, pois, entendeu pela expressão do cipaio que seu esposo morreu. Caminha pelo pátio e começa a se lamentar, cambaleante. Sai e cai de joelhos; algumas pessoas e Zito a ajudam a se levantar. É confortada por pessoas desconhecidas. 
Figura 6

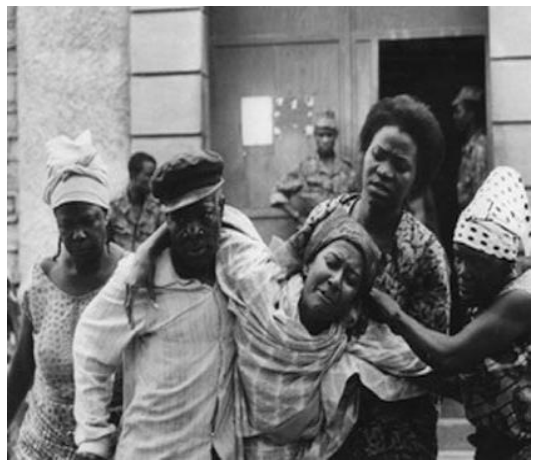

Legenda: Maria (Elisa Andrade) consolada por pessoas estranhas depois de saber da morte de Domingos. Petelo (Jean M’Vondo), à esquerda, ajuda a carregá-la.

Algumas mulheres a levam a uma casa, a envolvem com um manto negro e lamentam. Uma delas roga para que pense no futuro de seu filho, enquanto uns homens jogam baralho.

Músicos, que cantam e tocam em cima da carroceria de um carro, são seguidos por crianças. Fazem parte da festa política, organizada pelo líder Mussunda. Os músicos oferecem uma canção "Mama uelelê" para os colegas que estavam na prisão. Chegam Petelo e Zito e anunciam para Mussunda, Xico e Miguel a morte de Domingos. Zito e Mussunda choram copiosamente e o alfaiate comunica aos participantes da festa sobre o ocorrido.

Às margens do rio caudaloso inicial, Mussunda, Xico e Miguel reúnem-se meio as pedras e conversam com um operário sobre a vida de Domingos Xavier:

\footnotetext{
MIGUEL: - Nós viemos para te dar uma notícia. Nosso companheiro Domingos Xavier morreu na prisão.

OPERÁRIO: Como então?

MIGUEL: Domingos foi torturado, mas não falou. Nada disse até o fim.

MUSSUNDA: Agora é preciso mais coragem. Ficas no lugar dele. A dirigir o grupo aqui na obra. Temos de alastrar o movimento no mato. E o apoio do mato será cada vez mais necessário para o trabalho nas cidades.

MIGUEL: Já sabemos que a PIDE quer levar os presos da Casa de Reclusão para o Tarrafal.

MUSSUNDA: Portanto, o movimento já decidiu, de libertar nossos companheiros nas prisões. E a data já está fixada: 4 de fevereiro.
}

Essa cena, de caráter histórico- didático, que menciona o encontro nas imediações da barragem, junto ao rio Kwanza, entre os três membros do movimento político - Mussunda, Xico e Miguel - com um operário que seria o sucessor de Domingos no trabalho político, não existe na novela A vida verdadeira de Domingos Xavier. Ela evoca um acontecimento muito importante da história angolana: o assalto que foi realizado no dia 4. de fevereiro de 1961, em prédios militares de Luanda, cuja audácia foi apropriada por membros do MPLA, para dar importância à sua militância política. 
No mesmo episódio final, Miguel faz referência ao campo de concentração de Tarrafal (Cabo Verde), menciona, de forma velada, o presídio onde ainda estava o preso político, o escritor José Luandino Vieira em 1972, ano em que o filme foi realizado.

\section{Conclusão}

A adaptação cinematográfica da narrativa A vida verdadeira de Domingos Xavier (1961), de José Luandino Vieira, concretizou-se em Sambizanga (1973). A narrativa cinematográfica analisada revela elementos elencados por Hutcheon: a transposição intersemiótica de um sistema de signos (palavras) em imagens (filme); a adaptação da obra como sobrevida, a escolha temática como "engajamento político e história pessoal” e a representação do tempo.

Sambizanga apresenta o histórico levante de 4 de fevereiro de 1961, que fora mencionado na narrativa luandina, e humaniza a trajetória de um honesto operário e pai de família, que morre por causa de torturas violentas. E evoca cenas urbanas de bairros periféricos (musseques) e, de outro, a paisagem do centro da cidade de Brazaville (Luanda), em 1972.

O filme é coletivo em prol da elaboração de uma mensagem política sobre Angola, que se revela na opção da diretora Sarah Maldoror, companheira de um dos roteiristas, Mário Pinto de Andrade, militante do MPLA, pela novela de Luandino.

Maria do Carmo Piçarra, no artigo, Os cantos de Maldoror: Cinema de libertação da realizadora romancista, traça um panorama geral sobre a cinebiografia de Sarah:

Quanto à obra de Sarah Maldoror, cineasta "engajada" nas lutas de libertação dos povos
africanos, a dimensão poética do seu cinema político, com enfoque na luta dos
movimentos de libertação dos países africanos de língua portuguesa, faz extravasar a
categorização do seu cinema como militante. Para isso muito contribuíram as
adaptações cinematográficas das obras de Luandino Vieira, potenciadoras de uma
abordagem cinematográfica singular, no contexto do cinema militante feito para apoiar
e dar a conhecer as lutas pelas independências então em curso, em que o uso de
elementos ficcionais é uma constante potenciando a densidade e poesia das obras.
(PIÇARRA, 2017: p. 14)

A representação do tempo em Sambizanga é cronológica, embora a narrativa de Luandino se apresente mais complexa com evocações do protagonista de sua cela no Posto dos Musseques, em Luanda, de episódios de sua vida: de sua infância perto do rio Kwanza, das brincadeiras com balões e papagaios de papel com o filho do administrador, da vida no alojamento de operários negros da barragem etc.

O filme identifica o nome PIDE (Política Internacional de Polícia do Estado) em uma placa na frente de um edifício, onde Maria, chega, mas é escorraçada pelos agentes sem sequer ter a possibilidade de fazer perguntas. A novela de Luandino não menciona o nome do 
departamento de opressão do estado salazarista no ultramar. Na cena final de Sambizanga, o militante Miguel, entretanto, diz no encontro acima mencionado: "Já sabemos que a PIDE quer levar os presos da Casa de Reclusão para o Tarrafal”.

Outro episódio original do filme foi o convite de Silvestre para Domingos visitá-lo em sua casa e a entrega de panfletos pelo tratorista a um colega no acampamento.

Da narrativa de Luandino Vieira não foram reproduzidos os vários tipos de tortura que acabaram em dois três dias com a vida de Domingos.

O filme Sambizanga tem caráter bilíngüe. No artigo Literatura angolana em tempos de revolução: De A vida verdadeira de Domingos Xavier a Sambizanga, Francisco E. Almeida dos Santos e Joel Cardoso mencionam que:

\begin{abstract}
Sarah Maldoror substitui essa língua literária transculturada pelo multilinguismo presente em Angola. Sambizanga é um filme bilíngüe. Nele, os personagens comunicamse em português, língua oficial do país, e em quimbundo, língua muito usada em Luanda e no Kwanza, regiões onde se passa a história. Dessa forma, o filme assume um caráter mais realista e documental, apresentando a realidade lingüística concreta dos falantes angolanos, em lugar da língua literária inventada de Luandino Vieira. (SANTOS; CARDOSO, 2017: p. 39)
\end{abstract}

Fato é que o filme tem diálogos em quimbundo, que não somente causam ruptura na narrativa, como são incompreensíveis para muitos. A opção bilíngue limita a compreensão de parte do público. Os subtítulos em inglês mostram que as falas em português estavam resumidas. Resta saber se o mesmo procedimento foi adotado nos diálogos em quimbundo.

A realização e apresentação do filme na França e em Portugal, em 1973, um ano antes de ter acabado a guerra de independência de Angola (1961-1974), manteve viva a a trajetória de Luandino Vieira como preso político até 1972. Além de garantir em nível internacional uma "sobrevida" de sua narrativa, que mostra o engajamento político de pessoas de várias classes sociais no início do processo de descolonização angolana.

\title{
Referências bibliográficas
}

AGOSTINHO NETO, António. Mussunda Amigo. In: . Poemas. 2.ed. Lisboa: União das

Cidades Capitais de Língua Portuguesa p. 11. Disponível em:< https://www.uccla.pt/sites/default/files/colectania poemas ag ne to.pdf>. >. Acesso em: 02 out. 2020.

COSME, Leonel. Cultura e Revolução em Angola. Lisboa: Ed. Afrontamento, 1978.

HUTCHEON, Linda. Uma teoria da adaptação. Trad. de André Cechinel. . 2. ed. Florianópolis: Ed. da UFSC, 2013.

LARANJEIRA, José Pires. Literaturas africanas de expressão portuguesa. Lisboa: Universidade Aberta, 1995. 
LISBOA, Edmara. A vida verdadeira do Sambizanga em tempos de viragem. Revista Crioula, USP, $\mathrm{n}^{\circ} 17$, p. 1-11, jun. 2016.

MALDOROR, Sarah. "Em nome da moral fazem-se guerras". Entrevista concedida a Pedro Cardoso. Novo Jornal, Luanda, p. 14-16, 28 nov. 2008. Disponível em: $<$ http://mukuarimi.blogspot.com/2009/08/em-nome-da-moral-fazem-se-guerras.html>. Acesso em: 02 out. 2020.

PÉLISSIER, René; WHEELER, Douglas. História de Angola. Lisboa: Tinta da China, 2011.

PIÇARRA, Maria do Carmo. Luandino Vieira filmado por Sarah Maldoror (2014). Disponível em: $<$ http://www.redeangola.info/especiais/cinema-da-libertacao-luandino-vieira-filmado-porsarah-maldoror/>. Acesso em: 02 out. 2020.

Os cantos de Maldoror: Cinema de libertação da realizadora romancista. Mulemba, Rio de Janeiro: UFRJ, v. 9, $\mathrm{n}^{\circ}$ 17, p. 14-29, jul./dez.2017. Disponível em: https://revistas.ufrj.br/index.php/mulemba/article/view/14579/9753>. Acesso em: 02 out. 2020.

OS CAMINHOS DO 4 DE FEVEREIRO, 2 fev. 2016. Disponível em: ,http://www.redeangola.info/roteiros/os-caminhos-do-4-de-fevereiro/>. Acesso em: 02 out. 2020.

REIS, Carlos. Do realismo ao neo-realismo. In: Textos teóricos do neo-realismo português. Lisboa: Seara Nova, 1981. p. 13-41.

SAMBIZANGA (1972), filme de Sarah Maldoror. Disponível em: <https://archiveorg/detalis/SambizangaSarahMaldoror1973>. Acesso em: 02 out. 2020.

SANTOS, Francisco E. Almeida dos; CARDOSO, Joel. Cinema e literatura angolana em tempos de revolução: De A vida verdadeira de Domingos Xavier a Sambizanga. Revista Mulemba, Rio de Janeiro, UFRJ, v. 9, no 17, p. 30-42, jul./dez. 2017.

SARTRE, Jean- Paul. Que é a literatura. 2. ed. São Paulo: Ática, 1993.

SCHEFER, Raquel. Sarah Maldoror: o cinema da noite grávida de punhais. In: PIÇARRA, Maria do Carmo; ANTÓNIO, Jorge (Coords.). Angola, o nascimento de uma nação. Lisboa: Guerra \& Paz, 2015. v. 3- O cinema da independência, p. 139-152.

VIEIRA, José Luandino. A Vida Verdadeira de Domingos Xavier. Prefácio Memória Antiga num Tempo Novo, de Fernando Augusto A. Mourão. São Paulo: Ática, [1979].

Uma impressão tão forte que faz parte duma história futura. África, Lisboa, v. 1, nº 1, p. 11-14, jul. 1978.

ZAMPARONI, Valdemir D. Ficção e História em "A Vida Verdadeira de Domingos Xavier". Polifonia, p. 160-180. 1993 Disponível em: http://periodicoscientificos.ufmt.br/ojs/index.php/polifonia/article/view/1220/978>. Acesso em: 02 out. 2020.

\section{Iconografia}

Fig. 1- Sarah Maldoror. Disponivel em: <https://br.pinterest.com/pin/386254105527031947/>. Acesso em: 02 out. 2020.

Fig. 2- Luandino Vieira (2011). Disponível em: 
$<$ http://blogues.publico.pt/ciberescritas/2011/06/07/jose-luandino-vieira-amanha-na-feira-dolivro-do-porto/>. Acesso em: 02 out. 2020.

Fig. 3- Capa da 2.ed. da obra publicada pelas Edições 70, de Lisboa, 1975. Disponível em: <https://www.coisas.com/A-Vida-Verdadeira-de-Domingos-Xavier--JOSE-LUANDINOVIEIRA,name,228636320, auction id,auction details>. Acesso em: 02 out. 2020.

Fig. 4- Interrogatório de Domingos Xavier (Filme Sambizanga (1972), de Sarah Maldoror). Disponível em: <http://m.redeangola.info/especiais/sambizanga-o-nascimento-do-cinema-deuma-nacao/>. Acesso em: 02 out. 2020.

Fig. 5- Solidariedade dos presos com o companheiro morto (Sambizanga, 1972). Disponível em: $<$ https://www.filmmuseum.at/jart/pri3/filmmuseum/main.jart?j-j-

url $=/ \mathrm{en} / \mathrm{press} / \mathrm{presse}$ detail\&presse subkategorie $\mathrm{id}=1522917424274 \&$ presse kategorie $\mathrm{id}=1$ 52291742>. Acesso em: 02 out. 2020.

Fig. 6- Maria consolada por pessoas estranhas depois de saber da morte de Domingos. (Sambizanga, 1972). Disponível em: <http://afrobrasileiros.net.br/index.php/2016/11/06/mostra-em-sao-paulo-exibe-filmes-sobre-aindependencia-de-paises-africanos/>. Acesso em: 02 out. 2020.

\section{Filmografia}

CULTNE CINEMA- Filme "Sambizanga"- 1972- Sarah Maldoror. Disponível em: <https://www.youtube.com/watch?v=vJoYNJMVMr8>. Acesso em: 02 out. 2020.

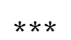

\section{Sobre a autora:}

Denise Rocha: Doutoranda em História pelo PPGHIS UFF, Bolsita CAPPES

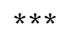

Artigo recebido para publicação em: 10 de abril de 2021.

Artigo aprovado para publicação em: 17 de julho de 2021.

\section{Como citar:}

ROCHA, Denise. Duplas linguagens angolanas: resiliência e resistência de um preso político na narrativa A vida verdadeira de Domingos Xavier (1961), de Luandino Vieira, e no filme Sambizanga (1973), de Sarah Maldoror. Revista Transversos. Dossiê: Africanizar: resistências, resiliências e sensibilidades. Rio de Janeiro, no. 22, 2021. pp. 162-182. Disponível em: 〈http://www.e-publicacoes.uerj.br/index.php/transversos〉. ISSN 2179-7528. DOI: 10.12957/transversos.2021.58646

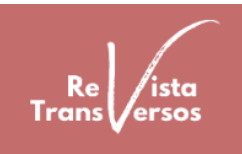

